\title{
CHANGES OF FUNCTIONS \\ OF POLISH STATE BORDERS AND THE DEVELOPMENT OF CROSS-BORDER CO-OPERATION AFTER 1989
}

\section{THE CHANGE OF NEIGHBOURS}

At the beginning of the 1990s Poland bordered upon three countries: the German Democratic Republic (GDR) - $467 \mathrm{~km}$ of common border, Czechoslovakia $-1330 \mathrm{~km}$, and the Soviet Union - $1257 \mathrm{~km}$ (Rocznik..., 1990). The relations between Poland and the other socialist countries were referred to through the formula of the concept of the possibly closest collaboration with the neighbours. Attention was being attracted to the fact that Poland, for the first time in its history, bordered with the countries having the same political and economic system, with the countries sympathetic for Poland, and the boundaries of the state were for the first time safe. The collaboration was enforced, and was taking place on the conditions dictated by the Soviet Union. It was undoubtedly occurring between the respective political elites, but there was absolutely no collaboration between the societies. The contacts of the populations of "befriended" countries were scarce, and the numbers of persons crossing the state borders - with definite exceptions - were limited. The border safeguards between the so closely allied countries - especially along the Polish-Soviet border - evoked rather those surrounding the concentration camps of the World War II than the ones proper for the line separating friendly countries.

After the GDR was incorporated in the Federal Republic of Germany, the Soviet Union disintegrated, and Czechoslovakia split, the geo-political position of Poland changed dramatically. In a short time period Poland changed all of its neighbours. Thus, in place of the borders with the GDR, Czechoslovakia and the Soviet Union, Poland now has borders with the Federal Republic of Germany: $467 \mathrm{~km}$, Czechia: $790 \mathrm{~km}$, Slovakia: $541 \mathrm{~km}$, Ukraine: $528 \mathrm{~km}$, Belarus': $416 \mathrm{~km}$, Lithuania: $103 \mathrm{~km}$, and Russia (the Kalinigrad District): $210 \mathrm{~km}$. The neighbours of Poland nowadays are either the members of the European Union (Germany) and of NATO (Germany, Czechia), or are candidates to these organisations (Lithuania, Slovakia), or try, more or less successfully, to establish the market economy and the economic, political, and even military co-operation with the western countries. 


\section{THE CHANGE OF FUNCTION OF THE STATE BORDER: INCREASE OF ITS PERMEABILITY}

The permeability of the border ought to be understood here as a "technical openness of the state border", associated directly with the physical possibility of crossing it by people and vehicles. The border permeability is the derivative of:

- the degree of formalisation of the border understood as a spatial barrier,

- the degree of development of the transboundary transport infrastructure, understood as the number of transport routes crossing the border and their technical condition.

The measure of the permeability of a border can be constituted by the intensity of the border traffic.

After the World War II Polish borders fulfilled the function of a barrier: military - against the foreign military aggression, economic - against the free flow of goods, and social - against the free flow of persons (Komornicki, 1999).

The social function of the border in the socialist countries was a derivative of the passport and visa policies, conducted by individual countries. Until 1989 Poland was one of the socialist countries featuring the most liberal regulations concerning outgoing trips. This was expressed through the relatively high facility of acquiring passports by the Poles and the signing by Poland of the agreements on the visa-less traffic with some of the western countries. Crossing of the state borders, though, was constantly limited by the currency policy (rationing of convertible currencies), customs policy (intended harassment at the border), and transport policy.

After 1989 the situation in all the countries of central-eastern Europe underwent rapid and essential changes. There was a liberalisation of the exit regulations, and, besides, Poland and some other formerly socialist countries signed the agreements on the visa-less traffic with all the countries of western Europe. The abolition of the obligation of having a visa with respect to Poles by the European countries was conducive to the establishment of new economic and social connections between Poland and the countries of western Europe. An advantageous circumstance was constituted also by the opening of the new, and modernisation of the old, border crossings.

In the years 1991-2001 the number of border crossings increased from 143 (Komornicki, 1999) to 242, of which overland crossings: from 124 to 206, sea crossings: from 15 to 18 , and air crossings: from 4 to 18 . There are especially many overland crossings along the southern border (87 with Czechia and 47 with Slovakia), and also along the western border (34 with Germany), while there are much less of them along the eastern border (7 with Russia, 3 with Lithuania, and 14 with Belarus' and Ukraine alike).

Thus, the length of the overland border per one border crossing is $14.8 \mathrm{~km}$ on the average, with the highest density of the crossings observed along the border with Czechia (9.1 km of the border per one border crossing), followed by the borders with Slovakia: $11.5 \mathrm{~km}$, and Germany: $13.7 \mathrm{~km}$. In the East 
of the country the same indicators were equal: $29.7 \mathrm{~km}$ for the border with Belarus', $30.0 \mathrm{~km}$ - with Russia, $34.3 \mathrm{~km}$ - with Lithuania, and $37.8 \mathrm{~km}$ - with Ukraine.

The number of persons crossing Polish state borders increased from 19.3 million in 1985 to 54.1 million in 1989 and 282.3 million in 1999. In 2000 the state borders were crossed by 278.4 million persons. While during the 1980s the outgoing trips of Poles dominated in the number of persons crossing the Polish border, starting with 1991 the in-coming trips of foreigners dominated.

Poland was in the past a country not too frequently visited by foreigners (3.4 million in 1985). The systemic and economic changes caused that in the years 1989-1995 the number of incoming trips of foreigners increased almost tenfold: from 8.2 million in 1989 to 82.2 million in 1995 . In the subsequent years there was a further increase of the number of incoming trips, but not as dynamic as before.

The foreigners coming to Poland can be classified into tourists and oneday visitors, whose stays are associated with the so-called trade tourism, and the goals of their trips were usually constituted by the bazaars located close to the border. The biggest numbers of foreigners come to Poland from Germany (53.8 million in 1999, 48.9 million in 2000), Czechia (13.5 million and 12.0 million, respectively), and Ukraine (5.3 million and 6.2 million, respectively), see Rocznik... (2000, 2001).

The revenue from the visits of foreigners amounted in 1999 to 6.1 billion USD, of which almost 2.8 billion USD were the expenditures of the tourists, and 2.7 billion USD - those of the one-day visitors. The remaining part of the revenues resulted from the sale of the tourist services abroad (Rocznik..., 2000).

The relatively liberal regulations concerning the trips abroad in the socialist Poland allowed Poles to go abroad more frequently (6.4 million trips in 1985) in comparison with the citizens of other socialist countries. The systemic changes caused that the numbers of trips of Polish citizens abroad increased from 19.3 million in 1989 to almost 56.7 million in 2000, meaning, however, that this increase was much smaller than in case of the visits of foreigners in Poland.

According to the data of the Border Guard the highest intensity of the border traffic of persons was observed in the year 2000 at the border with Germany - 136.9 million persons (49.1\%), followed by the borders with Czechia - 78.0 million (28.0\%), Slovakia - 20.8 million (7.4\%), Belarus' 12.9 million (4.6\%), and Ukraine - 12.0 million (4.2\%). The sea border was crossed by almost 7.9 million persons (2.3\%), 5.2 million (1.7\%) crossed the air border, 4.4 million (1.6\%) - the border with Russia, and 3.0 million (1.1\%) - the border with Lithuania.

In $198960.0 \%$ of persons crossing the borders did this over the road crossings, $33.7 \%$ - over the railway crossings, $5.0 \%$ - at the air crossings, and $1.3 \%$ - at the sea crossings. The number of persons crossing the borders 
over the roads increased in the years $1989-1999$ by more than the factor of eight: from 32.5 million to 265.8 million (258.6 million in 2000 ), while the number of those using railways decreased almost three times (from 18.2 million to 6.8 million, and 7.6 million in 2000). Consequently, in the recent years approximately $94-95 \%$ of travellers have been crossing the borders over the roads, which amounts to a requirement of modernisation of the road border crossings and construction of roads fulfilling the European standards.

Thus, while in 1980 the borders of Poland were crossed by 4.2 million vehicles (passenger cars, busses, trucks), this number increased by 1990 to 12.8 million (Komorowski, 1999), and by 2000 - to almost 77.7 million. The highest intensity of the cross-border traffic of vehicles in 2000 was observed on the border with Germany - 48.3 million vehicles (62.2\%), Czechia 16.1 million (20.8\%), Slovakia - 4.0 million (5.1\%), and Belarus' -3.3 million vehicles $(4.2 \%)$.

The border traffic of trucks increased from 295.4 thousand in 1980 to 1,077.5 thousand in 1990 (Komornicki, 1999), and then to 4,949.6 thousand in 2000. The highest intensity of the truck traffic in 2000 was observed at the border with Germany - 2,764.8 thousand (55.9\%), Czechia - 682.2 thousand $(13.8 \%)$, Lithuania -473.1 thousand $(9.6 \%)$, and Belarus' -411.6 thousand $(8.3 \%)$.

During the next 15 years Poland ought to construct $1540 \mathrm{~km}$ of motorways, $1500 \mathrm{~km}$ of expressways, and $2400 \mathrm{~km}$ of improved surface roads, capable of maintaining the heavy truck traffic.

In connection with the Polish aspirations to the membership in the European Union it is possible that already in the year 2004 Polish eastern border will become the outer boundary of the Union. That is why since several years the program is being carried out of adaptation of the system of protection of the Polish borders to the Union standards, conform to the Treaty of Schengen. In particular, Poland declared that its Border Guard would become fully ready to apply the Union regulations until the end of 2002. In fact, Polish Border Guard will in the future be responsible for the protection of the outer border of the European Union. The Guard concentrates currently on prevention and counteracting border criminality, and on the control of the traffic of person incoming to Poland and to the EU.

\section{THE DEVELOPMENT \\ OF THE CROSS-BORDER CO-OPERATION - EUROREGIONS}

The downfall of the communist system, the integration of Germany, and the opening up of the borders of Poland changed in an essential manner the status of the border-adjacent areas as well as their place in the administrative structure and the spatial organisation of economy. In the 1990s local societies of the border-adjacent regions of Poland started to conduct the cross-border co-operation with their neighbours, expressed through the establishment of a dozen or so Euroregions. 
A particular significance for the development of the cross-border cooperation along the boundaries of Poland should be attached to the formallegal prerequisites, consisting in the establishment of appropriate legal framework for this co-operation. The local self-governments and the regional authorities were unambiguously given the right to enter into and maintain contacts with foreign counterparts, and to implement the standards of crossborder co-operation, tested in western Europe. In latter terms the highest significance ought to be attached to the Madrid Convention and to the European Charter of the Territorial Self-Government. Poland, as a member of the Council of Europe since 1991, entered the Madrid Convention in 1993. In this manner the question of the legal aspect of the foreign activity of Polish regional and local authorities got a proper framework, pertaining not necessarily only to the border-adjacent areas. The second European legal act, side by side with the Madrid Convention, defining the formal-legal framework and the forms of participation of the local societies in the international contacts in accordance with the European standards, is constituted by the European Charter of the Territorial Self-Government, to which Poland became a party in 1993. The charter guarantees, in particular, the right of the local societies to collaborate with the local societies of other countries (Gminy..., 1997).

The idea of establishment of Euroregions had in Poland numerous advocates and opponents. ${ }^{1}$ The interest in the Euroregional co-operation is expressed primarily by the inhabitants of the border-adjacent areas, as well as the local and regional authorities. The border-adjacent areas of Poland are, as a rule, in a worse economic situation than those located in the centre of the country. The border-adjacent areas have not been in the past the locations of the investment projects important from the point of view of the entire national economy.

Ultimately, 15 Euroregions have been established along the borders of Poland. The total area encompassed by the Euroregional co-operation in Poland amounted at the beginning of 2000 to 115,100 sq.km $(36 \%$ of the country's territory), and was inhabited by 11.9 million persons ( $31 \%$ of the total population).

It was considered that the main objectives of the Euroregions consist in:

- the increase of the economic potential and the decrease of unemployment;

— the development of the good neighbourly contacts;

\footnotetext{
1 A discussion took place at the beginning of the 1990s in the Polish Diet concerning the purposefulness of inclusion of Polish border-adjacent areas to Euroregions. The sceptics spoke of the threat to the state sovereignty, mainly from the side of the western neighbours. There were even some, who maintained that the co-operation along the rivers Odra and Lusatian Nysa would lead to the disintegration of the Polish state. Similar apprehensions were voiced beyond the eastern border of Poland, especially in Belarus', Lithuania, and Ukraine, where the representatives of certain political forces warned against the Polish intriguing and the imperialist inclinations.
} 
Euroregions along the borders of Poland

\begin{tabular}{|c|c|c|c|c|c|c|}
\hline \multirow[t]{2}{*}{ Euroregion } & \multirow[t]{2}{*}{$\begin{array}{c}\text { Parties } \\
\text { to collaboration } \\
\text { ther than Poland }\end{array}$} & \multirow[t]{2}{*}{$\begin{array}{l}\text { Year of } \\
\text { establish- } \\
\text { ment }\end{array}$} & \multicolumn{2}{|c|}{$\begin{array}{l}\text { Surface area } \\
(\text { sq.km) }\end{array}$} & \multicolumn{2}{|c|}{$\begin{array}{c}\text { Population } \\
\text { number in 2000 } \\
\text { (thousand) }\end{array}$} \\
\hline & & & Total & $\begin{array}{c}\text { In } \\
\text { Poland }\end{array}$ & Total & $\begin{array}{c}\text { In } \\
\text { Poland }\end{array}$ \\
\hline Total & & & 425,994 & 115,095 & 35,996 & 11,874 \\
\hline Pomerania & $\begin{array}{l}\text { Germany, } \\
\text { Sweden }\end{array}$ & 1995 & 31,108 & 8,791 & 2,966 & 1,014 \\
\hline $\begin{array}{l}\text { Pro Europa } \\
\text { Viadrina }\end{array}$ & Germany & 1993 & 11,645 & 7,128 & 895 & 447 \\
\hline $\begin{array}{l}\text { Sprewa- } \\
\text { Nysa-Bóbr }\end{array}$ & Germany & 1993 & 9,656 & 7,844 & 908 & 632 \\
\hline Nysa & $\begin{array}{l}\text { Germany, } \\
\text { Czechia }\end{array}$ & 1991 & 12,193 & 4,124 & 1,759 & 556 \\
\hline Glacensis & Czechia & 1996 & 8,351 & 1,902 & 940 & 199 \\
\hline Pradziad & Czechia & 1997 & 4,078 & 1,613 & 342 & 214 \\
\hline Silesia & Czechia & 1998 & 1,469 & 1,247 & 359 & 240 \\
\hline $\begin{array}{l}\text { Cieszyn } \\
\text { Silesia } \\
\end{array}$ & Czechia & 1998 & 1,528 & 928 & 657 & 297 \\
\hline Tatra Mts. & Slovakia & 1994 & 8,524 & 1,952 & 468 & 245 \\
\hline Carpathian & $\begin{array}{l}\text { Slovakia, } \\
\text { Hungary, } \\
\text { Romania, } \\
\text { Ukraine } \\
\end{array}$ & 1993 & 141,488 & 18,686 & 14,800 & 2,376 \\
\hline Bug River & Ukraine, Belarus' & 1995 & 82,212 & 29,269 & 5,263 & 2,687 \\
\hline $\begin{array}{l}\text { Niemen } \\
\text { River }\end{array}$ & $\begin{array}{l}\text { Belarus', } \\
\text { Lithuania }\end{array}$ & 1997 & 55,633 & 20,544 & 2,790 & 1,190 \\
\hline Baltic Sea & $\begin{array}{l}\text { Lithuania, } \\
\text { Russia, Latvia, } \\
\text { Denmark, } \\
\text { Sweden } \\
\end{array}$ & 1998 & 58,109 & 11,067 & 3,849 & 1,777 \\
\hline $\begin{array}{l}\text { Beskidy } \\
\text { Mts. }\end{array}$ & Czechia, Slovakia & 2000 & a & $\mathrm{a}$ & a & $\mathrm{a}$ \\
\hline Dobrava & Czechia & 2001 & $\mathrm{~b}$ & $\mathrm{~b}$ & $\mathrm{~b}$ & $\mathrm{~b}$ \\
\hline
\end{tabular}

a - the area of the Euroregion Beskidy was in 2000 equal 3,800 sq. km, of which in Poland $-1,200$ sq. $\mathrm{km}$; this area was inhabited by close to 770,000 inhabitants, of whom more than 300,000 (44.6\%) in Poland;

$\mathrm{b}$ - the units participating in the Euroregion Dobrava from the Polish side are: the county of Wałbrzych, the communes of Mieroszów and Głuszyca, and the Regional Association of Social Initiatives PRO-EURO from Wałbrzych, while from the Czech side - the towns of Metují and Meziměsti.

- undertaking of actions aimed at the strengthening of the regional awareness;

- protection of the natural environment on the transboundary areas (Kowalczyk, 1996). 
Two models of Euroregions took shape in Poland:

- the purpose-oriented association of communes;

- the inter-regional association.

The purpose-oriented associations of communes function first of all along the western and southern borders of Poland. They are formed by the selfgovernmental units, which, when associated, are registered by the court on the basis of the "Law on associations". The thus established organisation enters into agreements and forms the Euroregion together with the similar associations in the neighbouring countries.

The inter-regional association is established with the participation of the voivodship (province) authorities, and thus has an administrative-self-governmental character. This model dominates along the eastern and south-eastern borders of Poland.

The choice of the model depends upon the political specificity of the neighbours. While it turned out possible to enter into co-operation at the selfgovernmental level across the border with Germany (because the respective bodies existed), it was not feasible across the eastern border, because neither Ukraine, nor Belarus' have local authorities similar to the Polish ones.

Of special importance are the Euroregions established along the PolishGerman border. This border, namely, is nowadays the outer limit of the European Union. This means, in practice, that these Euroregions are a particular experimental field before the potential accession of Poland into the European Union.

The achievements to date in the domain of the fundamental task of the Euroregional co-operation, that is - the establishment of close contacts across the border - should be evaluated quite positively. There are definite successes in the field of cultural activities, environmental protection, and tourism. The highest expectations of the inhabitants of the border regions were related to the acceleration of the economic growth, but the effects with this respect are definitely the weakest. The main reason lies in the shortage of funds. While the border areas located in the European Union (here: in Germany) could take advantage of the INTERREG II programme funds, Polish communes could get support only from the limited means available within the PHARE CBS (CrossBorder Cooperation). The primary source of financing is constituted by the small sums from the communal sources (local taxation), sporadically — from the province budget, from the state budget, or from some kind of foundation.

The Euroregional co-operation gives the most pronounced - though not necessarily satisfactory - effects along the Polish-German border. The most important achievements include the establishment of the European University "Viadrina" (Słubice - Frankfurt on Oder), construction and modernisation of the border crossings, construction of roads and urban thruways, sewage treatment plants, modern waste dumps and waste utilisation plants, bicycle routes, renovation of historical monuments, extension of telephone networks, and even joint elaboration of the urban and architectural designs for the border-adjacent towns. 
The most important barriers to collaboration include, side by side with the shortage of funds, mentioned already before, the differentiated level of the socio-economic development on the two sides of the state border (except for the southern border of Poland), and a too big difference of economic interests of the two co-operating sides.

The cross-boundary co-operation to date made apparent the phenomenon of asymmetry in the economic development (along the western border) and the asymmetry in the development of local self-governmental institutions (along the eastern borders). The illusions that the establishment of a Euroregion is equivalent to an access to the unlimited funds from the European Union disappeared in the test of reality. The inhabitants of the Polish borderadjacent communes understood that the Euroregions have to rely mainly on their own financial means, and that their success depends upon the activity of the commune self-governments, meaning that the functioning of the Euroregions will bring tangible benefits for the communes only if they themselves are active. Signing an agreement on the establishment of a Euroregion is namely just a formality and a gentlemanly gesture, while the implementation of the agreement takes place in the direct contacts between the co-operating communes and people.

\section{REFERENCES}

Gminy przygraniczne [Border-adjacent communes; in Polish], Urząd Statystyczny w Jeleniej Górze, Jelenia Góra 1997.

Komornicki T., 1999, Granice Polski. Analiza zmian przenikalności w latach 1990-1996 [The borders of Poland. Analysis of changes in permeability in the years $1990-1996$; in Polish], Geopolitical Studies, vol. 5, IGiPZ PAN, Warszawa.

Kowalczyk A., 1996, Regionalizacja Polski w perspektywie doświadczeń europejskich [Regionalisation of Poland in the light of the European experience; in Polish], Prace $i$ Studia Geograficzne, vol. 18, WGiSR UW, Wydawnictwa Uniwersytetu Warszawskiego, 7-23.

Roczniki Statystyczne Rzeczpospolitej Polskiej, 1998-2001 [Statistical Yearbooks of the Republic of Poland, years 1998-2001; in Polish], GUS, Warszawa, 1998-2001. 